\title{
Trinia Reinforced Polymer as Core for Implants Superstructure
}

\author{
CARMEN BIRIS ${ }^{1}$, EDWIN SEVER BECHIR ${ }^{1 *}$, ANAMARIA BECHIR², FARAH CURT MOLA ${ }^{1}$, AURELIANA CARAIANE ${ }^{3}$, \\ ADRIAN VIOREL BADIU4, CHERANA GIOGA ${ }^{2}$ \\ ${ }^{1}$ Medicine and Pharmacy University of Tirgu Mures, Faculty of Dentistry, 38 Gheorghe Marinescu Str., 540142, Tirgu Mures, \\ Romania \\ ${ }^{2}$ Titu Maiorescu University of Bucharest, Faculty of Dentistry, 67A Gheorghe Petrascu Str., 031593, Bucharest, Romania \\ ${ }^{3}$ Ovidius University of Constanta, Faculty of Dental Medicine, 7 Ilarie Voronca Str., 900684, Constanta, Romania \\ ${ }^{4}$ Dental Laboratory, 68 General Gheorghe Manu Str., 900674 Constanta, Romania
}

\begin{abstract}
The intraosseous implants are the most used dental implants. The development of new classes of dental biomaterials determined the apparition of Trinia, a Computer-Aided Design/Computer-Aided Manufacturing (CAD/CAM) reinforced polymer, used for core in non-metallic prosthetic restorations, including implants superstructure. The aim of the study was to present the obtained results in the use of Trinia polymer as nonmetallic core on the abutments of Bicon implants. 35 patients were selected, 19 females and 16 males, aged between 31 and 60 years. After 18 months of results monitoring, we ascertained that Trinia reinforced polymer had a very good behavior in the oral cavity, and the patients did not complain about inconveniences due to the oral rehabilitation with this biopolymer.
\end{abstract}

Keywords: oral rehabilitation by dental implants, Trinia reinforced polymer

The statistics show that in Romania, over $70 \%$ of adults have at least one missing tooth, which affects the quality of life and the long-term health status of the entire body [1]. Also, many patients prefer to perform other types of prosthetic restorations than dental implant insertion, due to the fear and the relatively long completion period, and because of the higher costs of the surgical procedures [2]. The endosseous implants are the most used dental implants applied when the patients have a bone matching suitable for this type of implants. The use of implants for replacing absent teeth has only become possible after the development of appropriate biomaterials that integrate into the maxillary bones and meet requirements such as lack of corrosion, biocompatibility, resistance, tolerance to the buccal environment, and the ability to be osteointegrable $[3,4]$.

Bicon implant system has a sloping shoulder, which allows increased flexibility during implant placement. Thus ensures that the bone level is maintained well beyond the implant and the formation of aesthetic gingival contours. Conical closure of $1.5^{\circ}$ and a space less than 0.5 microns, provides leak tightness between the implant and the abutment and represents a bacterial barrier. This conical closure also allows adaptive positioning $\left(0\right.$ to $\left.360^{\circ}\right)$ of the abutment. Currently, Bicon-type implants have an integrated surface area increased by $30 \%$ than a screw implant of the same size. These allows for the formation of mature Haversian bone tissue similar to cortical bone tissue, between the implant fins [5-8].

The development of biomaterial classes required solving problems related to the type and design of the material used both on the natural and on the implant abutments $[9,10]$. Assimilation synthetic macromolecular compounds in chemistry and human health must respond to their complex utilization, problems that arise from their temporary or long-term contact of polymeric biomaterials with orofacial tissues [11,12]. Among these new class of biomaterials belong Trinia too, a CAD/CAM biopolymer for framework of non-metallic restorations. Trinia is a tooth shade multi-dimensional reinforced nano-hybrid polymer with multi-layered glass fiber, non-irritating, non-cytotoxic,

*email:bechir.edwin@gmail.com; Phone: (+40)723396969 machinable and non-combustible biomaterial, with low specific weight, and high bending and compressive strength [13-15].

These considerations were the motivation to carry out the presentstudy on the results in the use of Trinia reinforced polymer as core for the superstructures on Bicon implants.

\section{Experimental part \\ Materials and methods}

The study was conducted in the Dental Medicine Faculties of Bucharest, Tirgu Mures and Constanta, during the period 2013-2016. The 24 selected patients ( 15 females and 9 males) were aged between 31 and 60 years $(45.5$ years \pm 14.5 years), and benefited by the insertion of 35 Bicon implants. The group of patients selected for this study signed the informed consent for participation. The inclusion criteria in this study were represented by the patients aged 31-60 years, with dental conditions which requiring complex oral rehabilitation with implants and prosthetic restorations on implants or mixed aggregation. The exclusion criteria in this study were represented by the patients out of the age range of 31-60 years, with premalignant and malignant lesions detected in the preventive oncological examination, with atypical gingival proliferation, soft tissues/tongue hyperplasia, tumors, smokers and pregnant patients. In figure 1 is presented the distribution of the patients by gender, age and number of inserted Bicon implants.

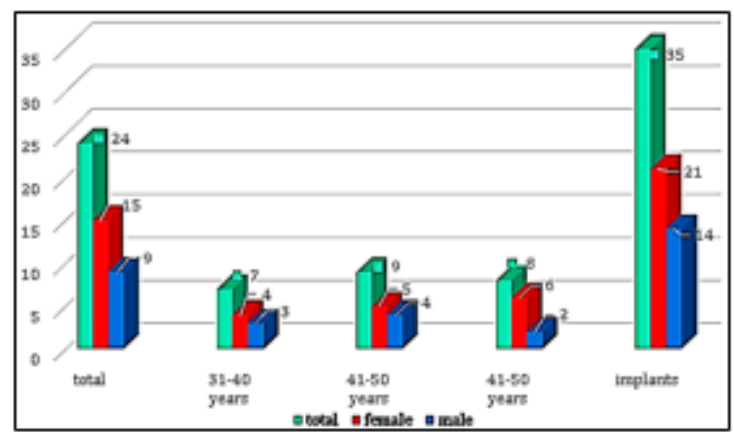

Fig. 1. Distribution of patients in the study by gender, age and number of inserted implants 

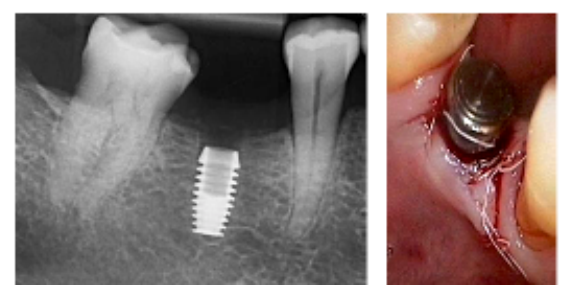

Fig. 2. Post-implant retroalveolar radiography at 4.6 area and the aspect of healing cap inserted on the Bicon implant

In figure 2 are presented the post-implantation retroalveolar radiography at the level of the absent right lower first molar (4.6: fig. 2-left) and the patient's intraoral aspect with the inserted healing cap on the Bicon implant (fig. 2-right).

The clinical and technical steps used in our study for achievement the superstructures with Trinia framework on Bicon implants consisted by the impression of prosthetic field and the Bicon implant area (fig. 3), casting the models, scanning of models, computerized design of the Trinia framework (with Pi Dental CAD/CAM Processing System: fig. 4 and fig. 5), milling the Trinia discs (with Cobra 4 Pi Denta milling machine: fig. 6), the adaptation of the Trinia core on the implant abutments in laboratory, achievement of the aesthetics layers of Gradia light-cured resin on the Trinia core (with Sibari SR 620 lightpolymerizator: fig. 7-
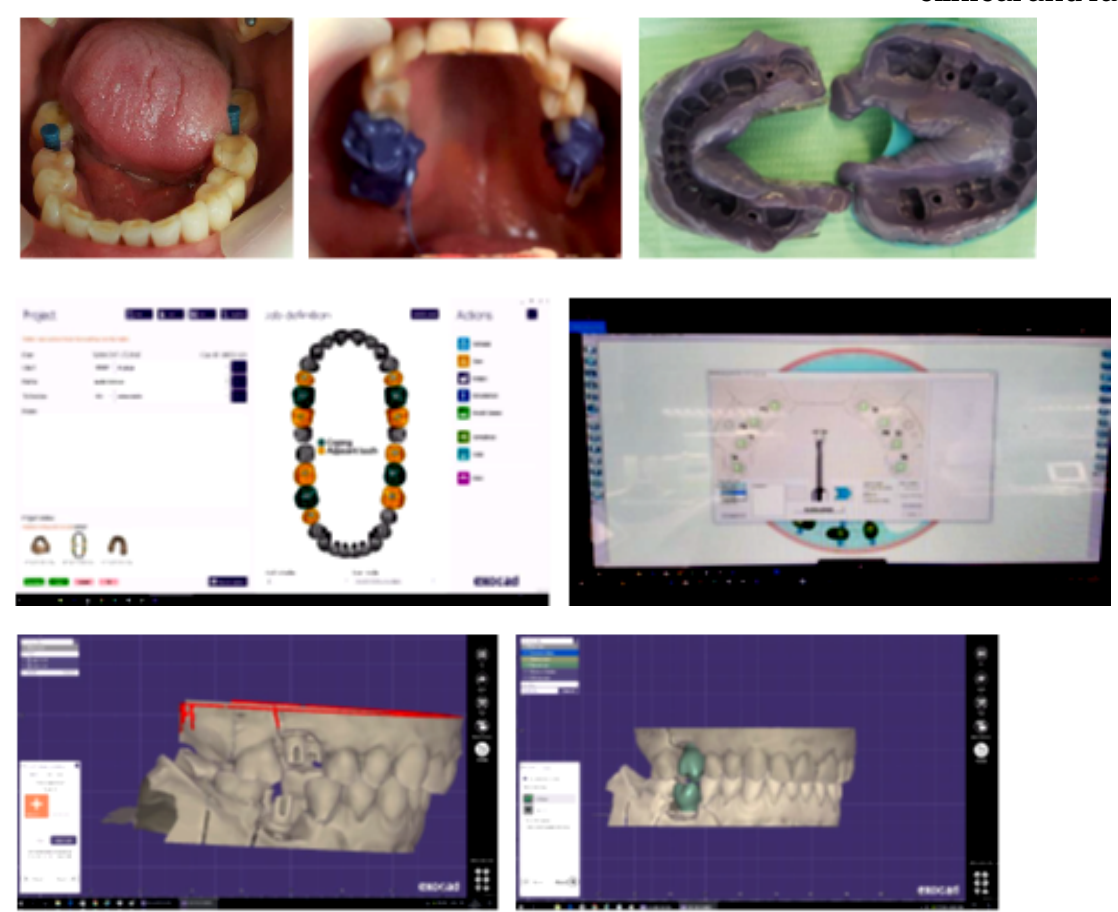

Fig. 4. Computerized design of future Trinia core

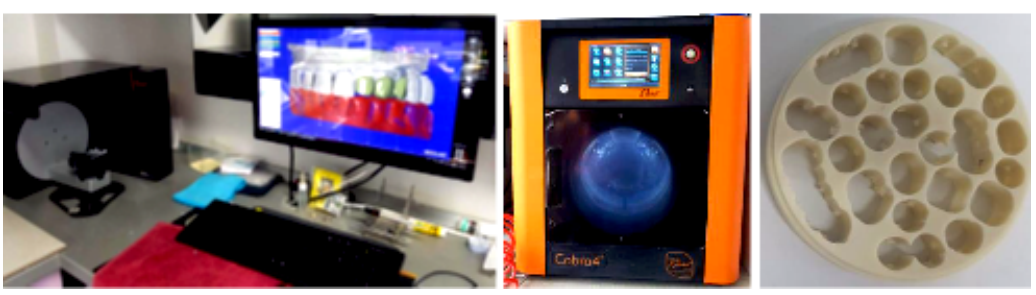

Fig. 5. Computerized design of future crowns
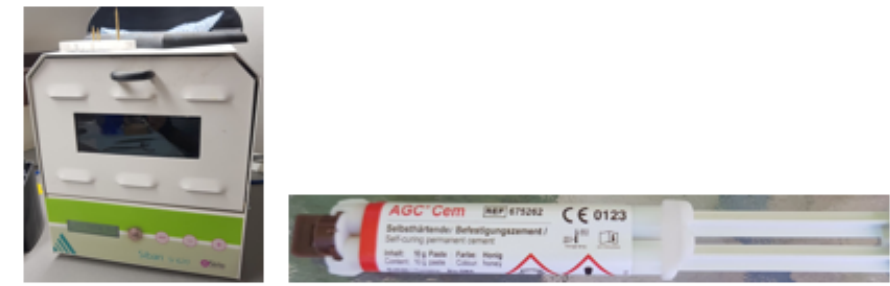

Fig. 7. The aspect of Sibari SR 620 light-polymerizator and of AGC CemWieland a self-curing resin
Fig. 3. Impression for the implantation superstructure of the Trinia biopolymer
Fig. 6. Computerized milling of Trinia core
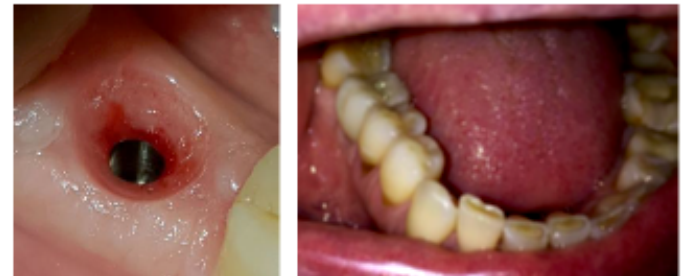

Fig. 8. Aspect of the implant in 4.6 area, after removing the healing abutment and the superstructure inserted on the Bicon implant 


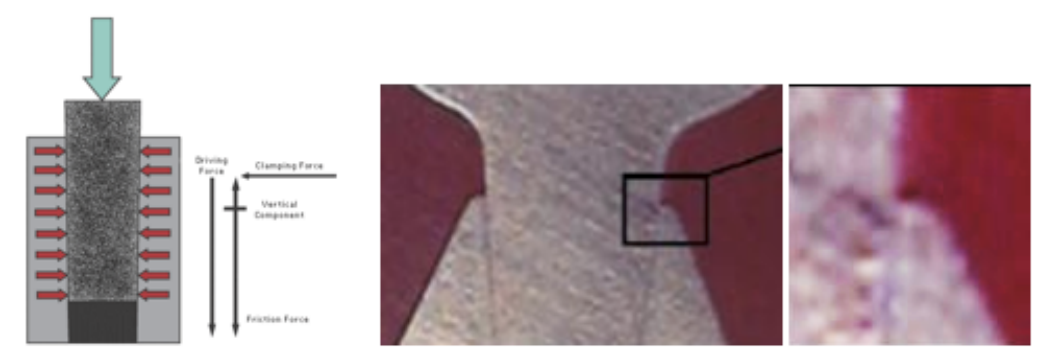

Fig. 10. Left: Retaining forces in locking taper abutments; Right: Interface between Bicon locking taper abutment and implant [17]

after the application of specific dental therapies. The nonmetallic superstructure on the Bicon implants has been manufactured with CAD/CAM technology, from Trinia core, covered with Gradia-GC light-cured composite, cemented in laboratory on the Bicon implants abutment. After 18 months of results monitoring, we found out that Trinia core covered with Gradia-GC light-cured composite, cemented in laboratory on the Bicon titanium abutment had a very good behavior in the oral cavity and the patients did not complain about inconveniences due to this biopolymer. Also, after 18 months of monitoring, we not found any deficiencies at level of superstructures or implants.

In the last period, dental implants insertion became a common dental surgeries. The success or failure of implants insertion depends on many factors, for example the health of the patients, used medication, but also the health and integrity of the periodontal tissues and bone tissue condition [16]. The Bicon locking taper abutment has no screw, but like a screw-retained abutment, it relies on friction to keep it intact. Bicon dental implant system does not require screwing and thus there is no way of causing torsional forces. Locking taper assemblies are rigid and can withstand high compressive axial forces and lateral forces without loosening. Assembly is achieved by driving the 1.5 degree morse taper into the matching socket in the implant. A high clamping force between abutment and implant is generated by this action. The difference (shown in fig. 10- left), is that this clamping force is almost lateral to the axis of the implant and therefore almost normal or perpendicular to the friction plane [17]. This means that lateral forces and moments about the abutment do not tend to wear down the surface asperity. This is also improved by the use of Ti-6Al-4V titanium alloy, which is considerably stronger and stiffer than commercially pure titanium, and cold welds better, particularly in the absence of oxygen $[18,19]$. The high friction force is the result of relative slip between the two friction surfaces occurring at high contact pressure. This results in the surface oxide layers breaking down and the asperity fusing, sometimes referred to as cold welding. Therefore (as shown in fig. 10 -right), there are no gaps between the abutment and the implant, unlike screw assemblies [17].

Trinia biomaterial consist of a multi-directional glass fiber network and multi-layer polymer, made of layers of glass fibers kept together by epoxy resin. After the producer, Trinia present special mechanical properties (through flexibility, durability) and can effectively replace the metallic component/framew ork of various dental restorations. One of Trinia's greatest attributes is its high flexural strength of $393 \mathrm{MPa}$ and compressive strength of $374 \mathrm{MPa}$ (parallel) and $339 \mathrm{MPa}$ (perpendicular). Stresses modulus is also another feature that adds to the superiority of this material, allowing for excellent tooth-like reproduction $[15,20]$. The dental restorations with Trinia core are made by mechanically shaping, the desired structure of the prosthetic restoration core is CAD [21], and no curing of Trinia is necessary in the dental lab to obtain properly core [22]. According to the research carried out by Hada et al.
[27], Trinia biopolymer showed anisotropic mechanical properties, which is why the deformation of a maxillary prosthesis was significantly reduced on the stress distribution model on the CAD/CAM system. In conformity with the researches of Krems et al [23], has been more and more frequently investigating partial and/or total fiberglass reinforcement restorations, which have much less water absorption. New generation of biomaterials used for prosthetic restorations have a very finely processed surface that does not irritate the mucosa of the oral cavity and does not allow the adhesion of biofilm to their surfaces $[24,25]$. There are several reasons for using non-metallic coronary restorations, because dental metal restorations are not esthetic, have a very good thermal and electrical conductivity, high weight and density, as well as allergen potential (Type IV allergy) and the relatively prolonged time required for the processing technology [26].

Occlusion needs to be evaluated in every patient because the occlusal problems are the result of the body trying to optimize its function in a dysfunctional environment and an individualized approach to occlusion is mandatory [28]. Incorrect occlusion and improper use of dental materials may induce premature loss of the patient's own teeth and of the implant functions due to mechanical deterioration, corrosion, or insufficient biocompatibility [29]. Currently, the researches are targeted for the improvement and the increasing of the biocompatibility in dental materials, and, in same time, for the increasing of the corrosion resistance of the materials that are in direct contact with the oral biological tissues [30].

\section{Conclusions}

Prosthetic restorations made of Trinia biopolymer core for superstructures on implants were considered slight and comfortable by patients;

The adaptability of patients to prosthetic restorations with the Trinia biopolymer core was facile;

Prosthetic restorations achieved by Trinia as core for superstructures on implants did not cause allergic reactions and did not presented crack or fracture;

The technology of making superstructures on implants by using Trinia reinforced polymeric core is quite complex, requiring both expertise and proper endowment of the dental office and of the dental laboratory.

\section{References}

1.***http://w w w.economica.net/clasamentul-clinicilorstomatologice-cine-sunt-romanii-dispusi-sa-achite-si-15-000-euro-casa-si-repare-dantura-intr-o-zi_115910.html

2.ANNIBALI S, VESTRI AR, PILOTTO A, et al, Annali di Stomatologia. 2010, 1(3-4):2-8

3.GAVIRIA L, SALCIDO JP, GUDA T, ONG JL. Journal of the Korean Association of Oral and Maxillofacial Surgeons. 2014, 40(2):50

4.BECHIR, E.S, BECHIR, A., GIOGA, C., MANU, R., BURCEA ,A., DASCALU, I.T, Mat. Plast., 53, no.3, 2016, p. 394

5.*** http://rontis.ro/divisions/dental/bicon/

6.***http://www.bicon.com/ 
7.*** http://www.bicon.com/b_short_implants.html

8.HI YS, EMANUEL KM, CHUANG SK, Implant Dent, 2011;20(2):125-130

9.WISE DL, TRANTOLO DJ, LEWANDROWSKI K-U, et al, Humana

Press, Totowa, NJ , Springer Book Archive, Online ISBN 978-1-59259197-8, p. 3-17

10.ANANTH H, KUNDAPUR V, MOHAMMED HS, et al, International Journal of Biomedical Science: IJ BS. 2015, 11(3):113-120

11.BOLOS, 0, C., BORTUN, C.M., CERNESCU, A., ARDELEAN, L., BOLOS, A., RUSU, L.C., Mat. Plast., 50, no. 1, 2013, p. 28

12.PACURAR M, BECHIR, ES, SUCIU, M, BECHIR, A, BIRIS, CI, CURT, MOLA, F, et al, Mat. Plast., 53, no. 4, 2016, p. 657

13.*** TRINIA_Brochure.pdf

14.*** Shofu Dental Corporation, Compendium of Continuing Education in Dentistry, October 2016, Vol. 37, Issue 10

15.*** https://www.dentalaegis.com/cced/2016/10/trinia-the-nextgeneration-of-cad-cam-and-metal-free-restorations

16.RUSU, LC, PIRTE, A, BORTUN, CM, HOINOIU, B, PODARIU, AC, ARDELEAN, L, NEGRUTIU, ML, SINESCU, C, PLES, H, Rev. Chim. (Bucharest), 66, no. 3, 2015, p. 396

17.*** http://www.bicon.com/news/n_publications_keating.html 18.BUCKLEY DH, Surface effects in adhesion, friction, wear, and lubrication. Elsevier, New York, 1981

19.*** http://www.dentalw est.ro/p/avantajele-sistemului-bicon/64/ro/
20.Shofu Dental Corporation, Compendium of Continuing Education in Dentistry, October 2016, Vol. 37, Issue 10,

21.*** http://ww w.shofu.com/en/w p-content/uploads/sites/2/2015/07/ IDT-CAD-CAM-eBook.pdf

22.*** http://www.trinia.com/

23.KREMS, C, SINESCU, C, FREIMAN, P.C, COJ OCARIU A.C, NEGRUTIU, M.L, PODARIU, CA, Mat. Plast., 52, no. 1, 2015, p. 36

24.NAGAYOSHI M, FUKUIZUMI T, KITAMURA C, et al, Oral Microbiol. Immun., 2004, 19(4):240

25.GALUSCAN, A, JUMANCA, D, BORCAN, F, SOICA, CM, IONESCU, D, RUSU, LC, ARDELEAN, L, CRAINICEANU, Z, Rev. Chim. (Bucharest), 65, no. 2, 2014, p. 190

26.BECHIR, A, COMANEANU, RM, SMATREA, O, RADULESCU, E.D, BECHIR, E.S, Ed. Printech, Bucharest, 2013, p. 192-231

27.HADA T, TAKAHASHI H, KAMIJ O S, et al, Dental Materials, 2016, Vol. 32, Supplement 1, e24 - e25

28.DAW SON PE, Functional Occlusion, Mosby; 1 edition, ISBN-13: 9780323033718, 2006 p. 582-602

29.HANCU, V, COMANEANU, R.M, COMAN, C, FILIPESCU, A.G, GHERGIC, D.L, COTRUT, M.C, Rev. Chim. (Bucharest), 65, no. 6, 2014, p. 706

30.BECHIR, ES, BECHIR, A, GIOGA ,C, MANU, R, BURCEA, A, DASCALU, IT, Mat. Plast., 2016, 53, no. 3, p. 394

Manuscript received: 17.07 .2017 